UDC $1 / 14: 27$

Balázs M. MEZEI

\title{
HAPPINESS, LIFE, LIBERTY \\ (A Catholic View)
}

\begin{abstract}
Happiness, life and liberty are central terms in the history of philosophy. At the same time, they belong to the core of Christianity. We find these key terms already in the New Testament and we also find that reflections on these terms have defined their meanings in new ways throughout the centuries. I show the way how the original meanings have gradually changed. In contemporary reflections, we find interesting attempts to reform the traditional meanings, in which the influence of the natural sciences and twentieth century philosophies (such as phenomenology, existentialism, Marxism and post-modernism) have proven to be decisive. Christianity-oriented philosophies in contemporary academia, such as those of Michel Henry or Jean-Luc Marion, offer versions of these thoughts. The main defect of the traditional understandings may be seen simply their isolationist approach, that is to say, their approach to consider these terms as unrelated to one another. My own solution finds the common structure in the reality of revelation and considers life, liberty, and happiness as moments only insufficiently grasped by traditional approaches.
\end{abstract}

Keywords: Life, liberty, happiness, philosophy of revelation, phenomenology, history of ideas, catholicity.

\section{Introduction}

Life, liberty, and happiness are original terms of our human context that are often investigated in isolation from one another. The notion of life is one of the central terms of Christianity, especially important in the Johannine writings. ${ }^{1}$ Liberty is again one of the key terms in the theological structure of the

1 Most importantly: 'In Him was life, and the life was the light of men.', John 1:4. Throughout this text I use the Revised Standard Version of the Bible.
Pauline letters ${ }^{2}$ and have often been used with reference to its Biblical origin. Finally, happiness is not only the central term of Aristotelian ethics, but it has a focal role in the New Testament as well - even if eudaimonia (happiness) and makar (blessedness) may be interpreted as differing in their exact meanings. ${ }^{3}$ These terms, therefore, belong to the core of our traditions. No wonder that they have be-

\footnotetext{
2 Most importantly: '... the glorious liberty of the children of God.', Rom 8:21.

3 Cf. Matthew, Chapter 5.
} 
come influential in the emergence of modernity as well. Yet, in modernity, especially with the rise of the modern natural sciences, the meaning of these terms strongly changed. As a consequence, we often forget the long prehistory of these terms and tend to think that they belong merely to the legacy of modernity. The fact is, however, that the contemporary meanings of these terms cannot be properly established without taking into consideration their respective genealogies.

On the other hand, these terms belong to one another both in their historical context and contemporary meanings. Historically, life was considered to be the context in which happiness, through the means of liberty, can be realized. In other words, life is the matrix, liberty is the means, and happiness is the end. Life, even in the sense of Plato, already contains liberty and happiness; and in Christianity, the life of Christ is that which is embraced in freedom and it results in the eternal happiness of the 'beatific vision'. In modern theories, these connections are not so obvious. The reason of this is that life has become defined in the context of contemporary science where it appears to be merely a physical phenomenon. Liberty, in a similar way, is often deemed to be a subjective illusion or rather part of a unique terminology which may not be understood literally. Happiness is feeling good or, as some psychologists suggest, being in the 'flow'; it has nothing to do either with eudaimonia or a 'beatific vision' of the previous ages. In our modern understandings, there is not even one single meaning attached to these terms. Being post-Nietzschean in its core, our age insists at the individualistic pluralism of meanings.

Nevertheless, the situation is not hope- less inasmuch as we consider the importance our age attributes to freedom as the sum of liberties. Freedom is central, because it is the way in which modern individuals conceive themselves; authority is not only the enemy of freedom but even its shadow which needs to be undone. The shadowless brilliance of freedom shines forth in our contemporary awareness so intensely that it seems to be even more important than life or happiness.

\section{The Notions of Life, Liberty, and Happiness}

The Septuagint normally translates the Hebrew châyâh (H2422 $\left.{ }^{4}\right)$ with zoé (G2222), sometimes psuché (G5590). This expresses the richness of the original Hebrew term, a richness, however, lacking the clear and specified articulation of the Greek terms. It may be that the name of the Lord in the Old Testament, JHWH, is etymologically related to châyâh through the latter's meaning of quickening, movement, 'life' as is suggested by Ex $3: 14 .^{5}$ The third Greek term for life, bios (G979) is not used as a translation of châyâh; but it is applied in a number of times as translating 'days', (yowm, H3117), that is, a human life's duration. Châyâh is then a synthet-

4 I add Strong's numbers in brackets to the Greek and Hebrew words.

5 Here the answer to Moses' question to the Lord - 'What is your name? what shall I say unto them?' - is notoriously 'ehyeh asher ehyeh', in which the forms of the verb hayah (H1961) are used. That is to say, His name is to be expressed by the use of the verb 'being' and thus the name often applied to God YHWH - may be related to this verb as well. 
ic term which reflects the fundamental experience of life as movement.

The three terms for life in Greek are zoé, psuche, and bios. Etymologically, zoé and bios are of the same root, BiF; while psuche comes from the root expressing breathing. In philosophical texts, especially in Plato and Aristotle, zoé expresses the flow of life, such as in the Timaeus where Plato describes the 'everlasting' life of the universe (Plato, Timaeus 37d). On the other hand, bios expresses the way of life or perhaps a phase of a life. Both Aristotle and Plato speak of such forms of life. In the Laws, Plato describes four 'lives' - the life of self-control, the life of wisdom, the life of courage, and the healthy life. And there are their opposite forms of life, that is, the licentious, the foolish, the cowardly and the diseased forms of life (Plato, Laws 733d-734e). Plato maintains that each of the first four forms is more pleasant than its opposite. He concludes from this that the life of excellence with respect to the body or the soul - that is to say, the life that combines the first four lives - is more pleasant than the life of depravity, which combines the four opposite forms of life. At the same time, Plato speaks of the idea of an immortal or indestructible life (Plato, Phaedo 106d), which can never perish. This notion of an everlasting life parallels the later notions of an eternal life which I will consider below.

In his discussion of domestic economy in the first book of the Politics Aristotle lists five forms of life: the lives of the herdsman, the brigand, the fisherman, the hunter, and the husband-man (Aristotle, Politics 1256b). In the Nicomachian ethics, Aristotle distinguishes between the pleasurable, the political, and - as the highest form - the contemplative form of life (Aristotle, Nicomachian ethics 1095b; 1178a). Aristotle, nevertheless, uses bios to distinguish between the theoretical and the practical life. It is the theoretical life (bi$o s$ ) the living of which (zoé) leads to a kind of divine stature (Aristotle, Nicomachian ethics 1095b; 1178a). Human and divine life are thus considered in the same perspective: human life is partial and limited to certain forms of life, while divine life is the life of the master and it has an overarching character; this life is unperishable.

It is important to see that happiness is intrinsic to such an unperishable life in Aristotle's thought. The Greek eudaimonia is usually translated as 'happiness' and Aristotle was a sophisticated thinker enough not to deny some level of happiness to any form of life. However, as he makes it explicit at the end of the Nicomachean Ethics, 'the activity of God, which surpasses all others in blessedness, must be contemplative; and of human activities, therefore, that which is most akin to this must be most of the nature of happiness ${ }^{36}$ (Aristotle, Nicomachian ethics 1178b). God is alive and stays in a permanent activity. This activity is complete in every respect possible and thus divine happiness is perfect. Human happiness may become assimilated to divine happiness inasmuch as a human being follows the theoretical or contemplative life and 'men become gods by excess of virtue' (Aristotle, Nicomachian ethics 1145a).

6 The English translation is from Aristotle in 23 Volumes, Vol. 19. Translated by H. Rackham. Cambridge, MA, Harvard University Press; London, William Heinemann Ltd. 1934. See at http://www.perseus.tufts.edu/hopper/text?doc= Aristot. + Nic.+ Eth.$+1178 \mathrm{~b} \&$ fromdoc $=$ Perseus \%3Atext\%3A1999.01.0054. 
Liberty, nevertheless, does not appear to belong to the core of happiness. Rather, liberty (eleutheria, freedom) belongs to democracy as a political form and as a way of life. The principle of democracy as a political form is equality and the rule of majority. Accordingly, the principle of democracy as a way of life is that 'a man should live as he likes.' (Aristotle, Politics 1317b). However, either the rule of majority or the freedom to live as one likes is not conductive to happiness, according to Aristotle.

There are important shifts in the meanings of these terms in Christianity. The perspective of reaching 'eternal life' (zoé aionios) is above everything. Surprisingly, the New Testament is consistent in using the word zoé in this context, thus making clear differences between zoé, psuché and bios. Psuché as life is the living nature of an individual, and bios is the duration of the same life. Theologically, bios refers to 'the pride of life' (1 John 2:16), 'life in the world' (1 John 3:17) or even 'the riches and pleasures of this life' that choke the seed fell among the thorns (Luke 8:14). Thus bios comes to express worldly life, the life opposed to eternal life (zoé). This later, however, can be reached only by getting rid of bios or even by the taking down of psuché: 'For whosoever will save his life (psuche) shall lose it: and whosoever will lose his life (psuche) for my sake shall find it' (Mark 8:35).

Liberty (eleutheria, freedom) is already in the center of the New Testament: The liberty of glory, the liberty of the children of God, the freedom reached by the truth of Christ are all central expressions and point to a massive theological basis here with a strong emphasis on individual, moral, metaphysical and divine freedom. This emphasis becomes even strong- er in the theological reflections in Latin Christianity, which lead to the modern interpretations of freedom in an individual sense. Without the Biblical notion of eleutheria, we cannot properly understand the doctrines of human freedom, not even in Protestantism where we face a doctrine of theological predestination. But even predestination is a means to highlight the point of individual freedom, as is shown by Luther's work on The Freedom of a Christian of 1520. It is in the context of predestination that the free service of the Christian to God may be realized.

The modern trajectory of the notion of freedom may be followed by fleshing out the most influential doctrines emerging from the context I just described. Jesuit spirituality, Protestant pietism, Enlightenment political and moral theories, Kant's notion of human persons' coming of age, and also the important contributions of Fichte, Schelling and Hegel - all these influences flew together in the emergence of the notion and practice of radical freedom which culminated in Friedrich Nietzsche's notion of the will to power.

I do not have space here to show all the important details in this history. Let me refer merely to the important point that the fundamental notion of freedom is not merely the capacity of free option but rather freedom as originally free expression, manifestation, or revelation of something other than what is entailed in freedom itself. All the specific notions of freedom, such as free will, selfmastery, ownership, causation are dependent on the ontological notion of freedom as the originally free expression. Without the ontological notion of freedom, it becomes very difficult to relate the specific notions of freedom to one another (cf. O'Connor, 2010). In 
the genealogy of the notion of freedom, we witness not only the emergence of specific notions of freedom, but also a growing understanding of the ontological notion. This latter notion was understood thoroughly by Martin Heidegger (cf. Heidegger, 1993, p. 123).

I want to emphasize that in the modern notion of freedom it is not the usual distinction between negative and positive freedom that is essential, but rather freedom as destruction and freedom as creation, as is beautifully described in Friedrich Schiller's classical poem The Song of the Bell. ${ }^{7}$ Nietzsche's notion of freedom as creation does not belong, according to his intention, to the destructive, but rather to the creative kind of freedom. In my view, it is this kind of creative freedom that is identified as philosophical courage by John Paul II in his encyclical letter Faith and Reason:

'I cannot but encourage philosophers be they Christian or not - to trust in the power of human reason and not to set themselves goals that are too modest in their philosophizing'

(John Paul II, Pope, 2001, § 56).

7 See especially these lines:

'BENEF'CENT is the might of flame,

When o'er it man doth watch, doth tame,

And what he buildeth, what he makes,

For this the heav'nly powers he thanks;

Yet fright'ning Heaven's pow'r will be,

When from its chains it doth break free,

Embarking forth on its own track,

Nature's daughter, free alack.'

Translated by Marianna Wertz,

Retrived from

https://www.schillerinstitute.org/fidelio_archiv e/2005/fidv14n01-02-2005SpSu/fidv14n01-022005SpSu_036-

friedrich_schillers the song_of.pdf.

\section{Relationships Among the Terms}

The historical development of our terms clearly shows two kinds of change: First, a change in the content of the terms, and second, a change in their relationship.

As to the first, it is important to note that merely on the grounds of Hellenism we cannot speak of 'eternal life' properly speaking. 'Eternal life' was seen by the Hellenistic authors, Plato and Aristotle included, in terms of a perennial life, that is a life co-temporal with the universe. The philosopher may reach this co-temporality by practicing the virtues or rather by realizing happiness given in the contemplative form of life. It is telling that the New Testament uses bios, an important term for the expression 'contemplative life' rather disapprovingly as 'the pride of life'. Instead of bios, it is zoé that is applied consistently in the New Testament to express the notion of eternal life. But for Christianity, this eternal life is not the life of the universe, but rather the life of the timeless God who stands above the universe as its creator. Thus, eternal life becomes something emphatically otherworldly, metaphysical, or ultimately theological.

Yet the anthropic emphasis of Christianity - given already in the doctrine of the two natures of Christ - led to the emergence of the notion of natural life as opposed to the supernatural life. The 'earthy man' is opposed to the 'heavenly man' (expressions by St. Paul ${ }^{8}$ ) and similarly, earthy or natural life is opposed to the heavenly or supernatural life. In this opposition there opens up the possibility of

8 'The first man is of the earth, earthy: the second man is the Lord from heaven', 1Cor $15: 47$. 
the slow articulation of the notion of a natural life, a notion which leads step by step to the emergence of the study of life in biological nature. In early biology, life is seen as a spontaneous emergence out of basic matter, especially water; and human life is also interpreted as coming from the same source in its physical shape. The biological notion of life, which has been the result of the long development of the early natural sciences, led to the universal notion of life in terms of a biological evolution. Darwinian evolution seems to have given the appropriate answer to the burning question of the relationship among living organisms. Yet it could not answer the question of the origin of life, because it was not its purpose; the origin of life remained and perhaps still remains a mystery in the Darwinian framework. Today, Darwinian theory is sometimes said to be challenged by alternative theories, such as 'intelligent design' which - in spite of the strong opposition to its fundamental claims - seems to have a number of points concerning the nonreducibility of well-arranged primitive complexes. Yet it is genetics that poses a more robust danger to Darwinism, because genetic wholes are by definition pre-arranged patterns which direct, and are not directed by, evolutionary processes. ${ }^{9}$

In contemporary biology, the remnants of the ancient notions of life almost fully disappear. Instead of an original life-force - worldly or other-worldly - we are presented with biochemical processes which can be mathematically described and even modelled in such a

9 For a discussion of the logical problems of natural selection, see Fodor \& Piattelli-Palmarini, 2010. For a more robust statement of the basic problem with the theory of natural evolution, see Jeanson, 2014. way that the production of artificial living organisms seems to be a realistic goal of science. The notion of life today overlaps with the notion of intelligent machines, such as computers, which are capable of producing symptoms similar to the symptoms of living organisms. Reception of and reaction to input in a sophisticated fashion seems to be the most fundamental feature of life and such a feature is reproduced in ever more complex forms in artificial organisms. The general awareness of the similarity between organisms and machines is increasingly present in popular culture (see for instance the movie Ex machina of 2015). In scientific circles, however, researchers are more cautious with hasty identifications and are also aware of the problems the fact of life raises in a seemingly lifeless universe. Robert Lanza's biocentrism may be mentioned here as a contemporary form of a pan-biological theory which can also be found, in an archaic sense, in the works of Hellenistic authors (Lanza \& Berman, 2009).

Similar developments can be observed with respect to the meanings of happiness and liberty. The general tenor of these developments is the ever stronger articulation of a sensual understanding of happiness and a progressively individualistic understanding of liberty. Happiness is getting satisfied and getting satisfied is not merely having enough food, but rather having all the various, even secondary desires satisfied, such as for instance the desires to possess some products of a technical civilization. The drive to have bigger cars is still present but not so much essential; it is more essential to want to have the latest technological achievements available on the market, for instance an electric car instead of a car with internal-combustion en- 
gine. Happiness has become technological and liberty seems to be identical with satisfying the drive to reach technological happiness. The question if this liberty has anything to do with freedom in a more complete sense may be answered by a diagram of the global disease of internet addictiveness on the basis of ever newer gadgets.

As to the second kind of change, in Hellenism happiness stood in the center; liberty was more or less insignificant and life was merely the matrix of happiness. Christianity inherited the centrality of happiness in the doctrine of the beatific vision, which is clearly a Platonic notion in its original form. ${ }^{10}$ The Christian form of this notion speaks of beatitude, because it synthesized in itself the eudemonic doctrines of Hellenistic philosophy and the makarioi sayings of Jesus in Matthew, Chapter 5. The beginnings of Christianity, especially Johannine Christianity, saw life as the central notion: life as zoé, as eternal life, as the new life in Christ has become central and still dominates many parts of Orthodox Christianity. Latin Christianity, however, has been increasingly defined by the notion of liberty. What was merely an elementary teaching in Greek philosophy becomes now central: 'Then you will know the truth, and the truth will set you free' (John 8:32). Augustine, early natural theology, Scholasticism, Jesuit spirituality and Lutheran Protestantism represent the most important phases of the evolution of the notion of liberty which culminates, as I suggested, in Nietzsche's understanding of freedom in Zarathustra: 'Everything is freedom: thou

10 Plato emphatically writes in the Symposium that the highest purpose of human beings should be the search for the "vision of beauty itself’. Cf. Plato, Symposium 211e-212a. canst, for thou willest!' (Nietzsche, 1998). Martin Heidegger's formula - 'The essence of truth is freedom' - is a corollary to Nietzsche's dictum (Heidegger, 1993, p. 123). Twentieth century existentialism centered on the notion of unlimited freedom and this notion of freedom exploded the political existence of the Soviet Union: freedom defeated unfreedom.

Yet what we see today as a consequence of this epochal occurrence is rather the unleashing of uncontrolled developments in politics as well as in general culture. This unleashing of freedom threatens the basic structures of our world today.

\section{The Post-Modern Situation}

'Post-modernity' is a general term which can be applied to historiography as describing the epoch beginning at the end of the twentieth century, especially with the collapse of the Soviet system. In the sciences, post-modernity refers to the age of computers, the description of the human genome, and the emergence of nanotechnology. With respect to the sources of energy, post-modernity emphasizes the process of transition from fossil-based energy consumption to the use of solar energy. We need to ponder a little on the relevance of postmodernity to the fundamental notions I considered above.

Post-modernity has three possible attitudes with respect to its prehistory:

a) A return to an earlier paradigm;

b) The synthesis of earlier and divergent developments; and

c) The radical surpassing of all previous developments.

The first perspective dictates that our basic notions - happiness, life, liberty - may 
be revised on the basis of an earlier paradigm. Such a paradigm might be the Platonic or the Aristotelian approach to happiness. We indeed find such attempts, for instance the thought of Alasdair MacIntyre, which emphasize the importance of the proper understanding of earlier views (cf. MacIntyre 2007, p. 263). The typical mistake here is a one-sided understanding, for instance the misunderstanding of Aristotle as a proponent of virtue ethics, while Aristotle understood virtue ethics in a limited fashion and only as an alternative to 'eudemonic' ethics, that is, an ethics of divine intervention. Moreover, it is obvious that certain tenets cannot be used today, such as the notion of life as universal zoé, a zoé permeating the entire cosmos. Even the notion of the heavens - of which we have more or less seven in accordance with the Hellenistic and New Testament authors - may be either incomprehensible or misleading today (cf. Mezei, 2016a).

A different example of a return to earlier ideas is represented by Michel Henry. The French philosopher's emphasis on the notion of life may come from Hegel but in fact it is a notion without a conscious subject. Thus this notion of life is pre-modern rather than postmodern, because it cannot handle rationally the problem of freedom in its framework. Robert Lanza, mentioned above, is more articulate in that biological life is centered on the emergence of consciousness and thus life and consciousness seems to be just two sides of the same coin, the original stuff of the universe. Henry's notion of life seems to be insufficient inasmuch as it does not explain the centrality of consciousness, a centrality which is presupposed above all in the fact of Henry's writings (Henry, 2000).

The second perspective is more promis- ing, because it is possible to offer a synthetic understanding of the basic terms both on a historical trajectory and in a logical way. Thus, happiness, life and liberty could be understood as a historical sequence - just as I showed it above - and at the same time as moments belonging intrinsically together. Yet it is obvious that in such a synthesis, the whole must surpass the sum, because every genuine whole by definition surpasses its parts (the holos transcends the pan, as already Plato saw this logical state of affairs, sf. Plato, 1997, 226, Theaetetus 204b). Thus we need to identify the whole in which we situate our basic terms. It seems to me that such a structure can be a notion of reality, or rather reality as such as it is emerging throughout the centuries in a characteristic way in our human awareness. One good example here is the evolution of the notion of divine revelation which began with fairly confused and obscure notions and reached a unique clarity by the nineteenth century. At the same time, revelation proves to be the original selfdisclosure of reality. Analogously, when we offer a synthesis of the basic terms, we need to reflect on the emerging new whole in which these terms are defined (cf. Mezei, 2016b).

The third perspective articulates this point in its own, radical way. The entire tradition must be surpassed and transcended and an entirely new notion must be identified as the very goal of human beings. In the history of philosophy, we have had some proposals, such as Hegel's Spirit, the Overman by Nietzsche, the Event by Heidegger - or revisions of the divine by A.N. Whitehead, Charles Heartshorne, Emmanuel Lévinas, Michel Henry, Jean-Luc Marion or some other contemporary philosophical theologians, such as Charles Taylor. However, in my view, the perspective of sur- 
passing is just a strong version of the second perspective, that of a synthesis. The genuine synthesis entails the surpassing of its contents and the offering of a new whole in which those contents may be better understood. Thus I accept the third perspective as the most viable one inasmuch as it is seen as the emphatic articulation of the implications of the second perspective.

It is my understanding that the traditional notions of happiness, life and liberty were one-sided and fragmentary and also unable to develop the logical contents of these terms appropriately. That is the reason why happiness came to be redefined on the basis of sensualism with the rise of modernity as a reaction to the original failure of developing a more complex notion of happiness. And that is the reason why life lost its universal meaning in the same period and became confined to elementary biological forms isolated in a lifeless universe. And that is the reason why liberty was not able to halt its one-sided and destructive energies which broke out at the end of the eighteenth century and ultimately defeated more constructive traditions.

What we need today is a genuinely catholic view, that is, a historical, organic and dynamic understanding of reality - not in terms of a fragmentary empiricism or sensualism, not even as a return to some half-understood earlier idea, but rather as an organic continuation of earlier developments with all its ups and downs, failures and achievements. The most important aspects of contemporary science, such as quantum theory, may help us to understand better the realness of reality in our age. Or, as I suggested above, it is the notion of revelation which gives us the clue to such an understanding - inasmuch as we have the time and energy to dig deep into the history and contents of this notion. ${ }^{11}$ In the notion of revelation, the notions of happiness, life and liberty are synthesized in such a way that it offers more than a personal satisfaction, fulfillment, or freedom. It offers an incomparable whole in which happiness, life and liberty are disclosed as intrinsic moments of the reality of revelation.

One may of course ask if this overall notion of revelation may not represent a simple return to an earlier paradigm. If the notion is understood on the basis of its peculiar historical evolution, my answer is that it does not point to a return but rather to a progress, namely, a progress in which earlier latent or even unknown dimensions of this notion may come to the fore in a fashion which embodies option (c) among the possibilities listed above. To analyze this latter point I have already proposed the systematic study of the notion of revelation under the name of apocalyptics (Mezei, 2016b).

\section{Conclusion}

I have offered a catholic view of an important segment of our history of ideas with respect to the notions happiness, life, and liberty. I have pointed out that the meanings of these terms, taken in themselves, changed dramatically throughout the centuries. In this change, happiness and life became naturalized and liberty received an increasingly individualistic emphasis. During the twentieth century, the original meanings of these terms became untenable and there was no successful

11 For more details cf. Mezei 2013 and Mezei $2016 b$. 
attempt to revise and further develop either their contents or their relation to one another, or both.

If we recognize that we need to renew the contents of these terms and their internal relations, we have three possibilities: a) a return to an earlier paradigm; b) a synthesis of prehistorically divergent developments; and c) a radical surpassing of all previous developments.

The last two perspectives have proved to be identical, because a 'radical surpassing' by necessity entails a reasonable synthesis. There is no radical break with a pre-history without a rational interpretation of the same history and the offering of a venue to a higher level realization of this history. Thus, I propose that after the dominance of happiness, life, and liberty, we need to develop the proper understanding of reality in a new way. I term this way 'catholic' because of it overall, overarching, and universal character. The central term of this approach is - revelation. It is in the perspective of a renewed and elaborated notion of revelation that we understand both the importance and the unimportance of such basic terms as happiness, life, and liberty.

\section{REFERENCES}

Aristotle. (1941). Basic Works. Edited by Richard McKeon. New York: Random House.

Bible. (1946-2006). The Revised Standard Version. Retrieved from https://www.biblegateway.com/

Fodor, J., \& Piattelli-Palmarini, M. (2010). What Darwin Got Wrong. New York: Farrar, Straus and Giroux.
Heidegger, M. (1993). Basic Writings. (D.F. Krell, Ed.). San Francisco: Harper.

Henry, M. (2000). Incarnation. Une philosophie de la chair. Paris: Seuil.

Jeanson, N. T. (2014). Darwin vs. Genetics: Surprises and Snags in the Science of Common Ancestry. Acts \& Facts. 43 (9). Retrieved from http://www.icr.org/article/darwin-vsgenetics-surprises-snags/.

John Paul II, Pope. (2001). Fides et Ratio. In The Encyclicals of John Paul II. (M. Miller, Ed.). Huntington: Our Sunday Visitor.

Lanza, R., \& Berman, R. (2009). Biocentrism: How Life and Consciousness are the Keys to Understanding the True Nature of the Universe. Dallas: Bonbella Books.

MacIntyre, A. (2007). After Virtue. A Study in Moral Theory. Notre Dame: University of Notre Dame Press.

Mezei, B. M. (2013). Religion and Revelation after Auschwitz. New York: Bloomsbury.

Mezei, B. M. (2016a). Renewing Christian Philosophy: An Outline. In O. Kenneth (Ed.) Christian Wisdom Meets Modernity. New York; London: Bloomsbury Publishing.

Mezei, B. M. (2016b). The Methodological Importance of the Notion of Divine Revelation in a Historical Perspective. Wisdom 2 (7) 63-76. doi:10.24234/wisdom.v2i7.161

Nietzsche, F. (1998). Also Spoke Zarathustra (Th. Common, Trans.). Retrieved from http://www.gutenberg. org/cache/epub/1998/pg1998.txt. 
O'Connor, T. (2010). Free Will. The Stanford Encyclopedia of Philosophy (Summer 2016 Edition), (E.N. Zalta, Ed.), Retrieved from

https://plato.stanford.edu/archives/su m2016/entries/freewill/.

Plato. (1997). The Complete Works (J.Cooper, Ed.). Indianapolis: Hackett.

Schiller, F. (2005. Spring/Summer). The Song of the Bell. (M. Wertz, trans.) Fidelio Journal of Poetry, Science, and Statecraft. Retrieved from https://www.schillerinstitute.org/fide lio archive/2005/fidv14n01-022005SpSu/fidv14n01-022005SpSu 036-

friedrich schillers the song_of.pdf. 